\title{
Site-suitability analysis for turmeric in Jaintia Hills of Meghalaya, India, using analytical hierarchical process and weighted overlay analysis: a comparative approach
}

\author{
Ashu Negi, Tapan Adhikari, Chandan Goswami*, B. K. Handique and \\ P. L. N. Raju \\ North Eastern Space Applications Centre, Umiam 793 103, India
}

India is the largest producer, consumer and exporter of turmeric (Curcuma longa L.). The Lakadong variety of turmeric is endemic to Jaintia Hills of Meghalaya, India. It is considered as the best quality turmeric containing $7.5 \%$ curcumin, which is about three times higher than the other varieties $(2-3 \%)$. This study identifies potential sites for turmeric cultivation in Jaintia Hills using geospatial techniques, viz. analytical hierarchical process (AHP) and weighted overlay analysis (WOA). WOA identified a total of $162,263.70$ ha suitable for the expansion of Lakadong variety of turmeric in Jaintia Hills, of which $18 \%$ was highly suitable, $31 \%$ moderately suitable and $32 \%$ was marginally suitable. In the case of AHP, $21 \%$ area was found to be highly suitable, $25 \%$ moderately suitable and $45 \%$ marginally suitable.

Keywords: Analytical hierarchical process, site suitability analysis, turmeric, weighted overlay analysis.

OVER the years, horticulture has emerged as one of the potential agricultural enterprises in accelerating the growth of economy in India. Its role in the country's nutritional security, poverty alleviation and employment generation programmes is becoming increasingly important. The agro-climatic conditions of Meghalaya, India, provide excellent condition for growing different horticultural crops, including fruits, vegetables, spices, plantation crops, and medicinal and aromatic plants of high economic value. Turmeric (Curcuma longa L.) has been used in India as a spice as well as in medicine since time immemorial. Turmeric (family: Zingiberaceae) is used as a condiment, drug, dye, cosmetic, and also in religious ceremonies ${ }^{1}$. India is the largest producer and exporter of turmeric in the world. Turmeric occupies nearly 1.55 million hectares ( $\mathrm{m} \mathrm{ha}$ ) (which is $6 \%$ of the total area under spices) in the country with average productivity of $3533 \mathrm{~kg} /$ ha (ref. 2). It can be grown with little care, and can turn a barren land or wasteland into

\footnotetext{
*For correspondence. (e-mail: chandangoswami@gmail.com)
}

productive land with a less effort, thus improving the rural livelihood ${ }^{3}$.

Lakadong, the local variety of turmeric is grown in Jaintia Hills, Meghalaya, India. This variety is indigenous to the Shangpong area of Jaintia Hills and is considered as the best quality turmeric with curcumin content as high as $7.5 \%$ (refs $4-6$ ). The variety has high market value; however, it has low-yield potential because of diseases like leaf spot and leaf blotch which limit its further expansion. The Indian Council of Agricultural Research (ICAR) Research Complex of the North Eastern Hill Region has developed a promising turmeric variety known as Megha Turmeric-1 to overcome these problems ${ }^{6}$.

The turmeric varieties having export potential can be expanded to other suitable areas for increasing the area under production. Suitable areas for growing turmeric can be assessed using the recent multi criteria decision making (MCDM) systems such as analytical hierarchical process (AHP) and weighted overlay analysis (WOA). Development of MCDM approaches took place during the 1960s to integrate numeral options, varied opinions into a potential new framework. AHP as a decision support system has gained popularity due to its ability to handle large amounts of heterogeneous data ${ }^{7,8}$. The ranks in AHP are generally judged by expert opinion. The consistency is assessed with the help of consistency ratio $(\mathrm{CR})^{9,10}$. Again, WOA is a similar kind of approach, however, it lacks the ability to check consistency, and both the rank and weight are judged using expert opinion, which again in many stages can result in a bias, or the opinion may vary from one expert to another.

\section{Study area}

Jaintia Hills has a total geographical area (TGA) of 3819 sq. km (Figure 1). The geographical extent of the Jaintia Hills district is between $25^{\circ} 01^{\prime} 16.11^{\prime \prime}-25^{\circ} 45^{\prime} 06.42^{\prime \prime} \mathrm{N}$ lat. and $92^{\circ} 48^{\prime} 35.09^{\prime \prime}-91^{\circ} 58^{\prime} 29.24^{\prime \prime} \mathrm{E}$ long. The elevation ranges from $76 \mathrm{~m}$ (at Dawki) to $1627 \mathrm{~m}$ (at Maryngksi). The soils of the Hills are dark brown to dark reddish-brown 


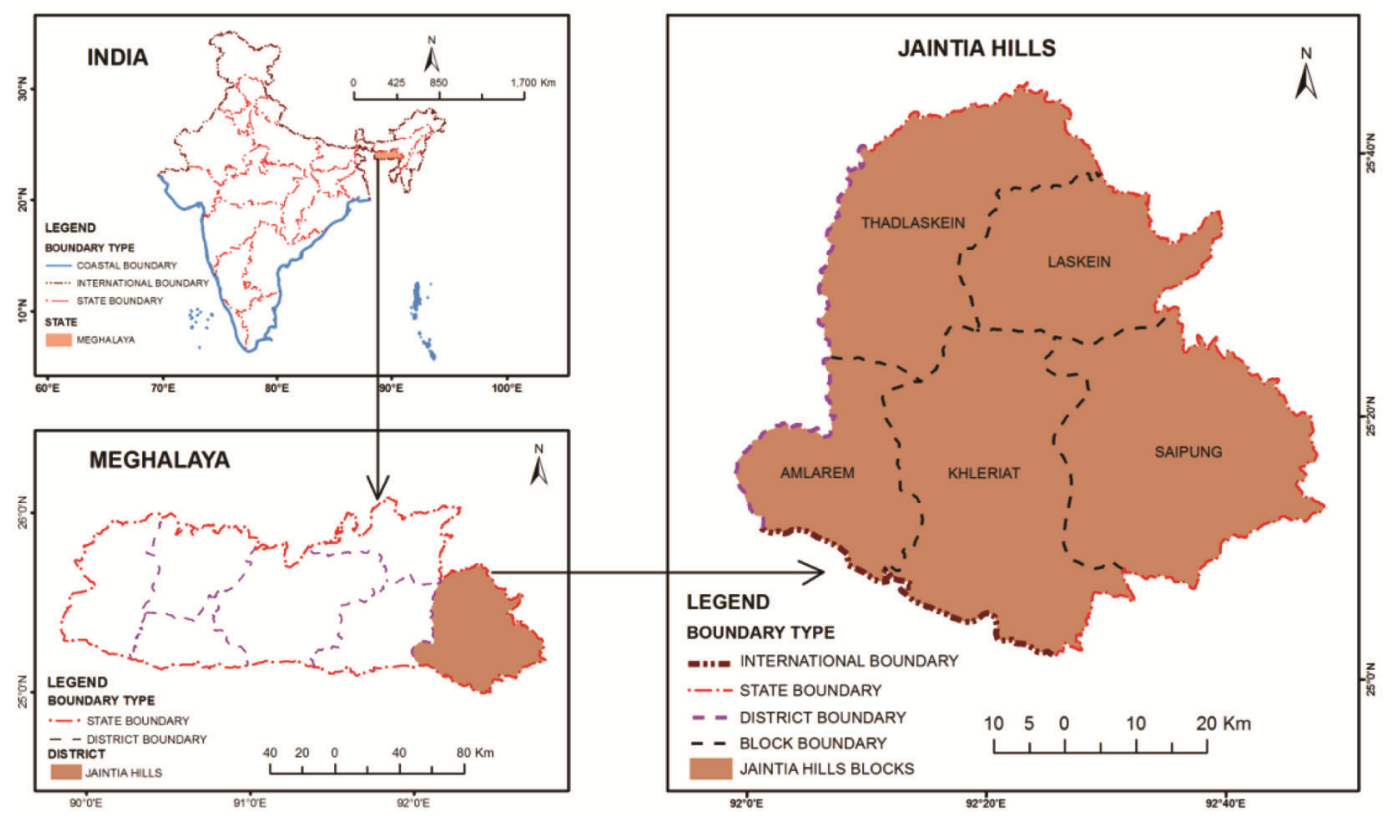

Figure 1. Map of the study area (Jaintia Hills, Meghalaya, India).

in colour, varying in depth from 50 to $200 \mathrm{~cm}$. The texture of soils varies from loamy to fine loamy ${ }^{11}$.

\section{Materials and methods}

Two satellite imageries (111/54 for 26 October 2015 and 18 March 2016) of Resourcesat-2 Linear Imaging Self Scanning Sensor-III (LISS-III) were utilized for delineation of major land-use land-cover (LULC) classes with on-screen digitization through visual image interpretation techniques using ArcGIS 10.2 software. Eight major LULC classes were identified in Jaintia Hills, viz. agricultural lands (AL), built-up lands (BUL), forest lands (FL), forest-tree-clad area-open (FTCAO), shifting cultivation-current (SCC), shifting cultivation-abandoned (SCA), wastelands (WL) and water bodies (WB). FTCAO, SCC and SCA were considered for the identification of potential sites for turmeric cultivation. In this context, only three classes have been considered because other land-use scenarios like many agricultural plots have been permanently dedicated for major agricultural crops and several land-cover classes, viz. water, reserve forest areas have been transformed into settlement, roads, industries and other developmental purposes; hence they cannot be easily transformed for the cultivation of turmeric. Accuracy assessment for LULC was carried out using standard methods ${ }^{12}$.

Soil maps on $1: 50,000$ scale $(50 \mathrm{~K})$ prepared by the North Eastern Space Applications Centre, Meghalaya in collaboration with Soil and Land Use Survey of India (SLUSI), New Delhi were used for extracting the required soil parameters, viz. texture, erosion, depth, soil drainage, $\mathrm{pH}$, available $\mathrm{P}_{2} \mathrm{O}_{5}$ available $\mathrm{K}_{2} \mathrm{O}$, etc. Land capability classes (LCCs) were interpreted from the soil $50 \mathrm{~K}$ map following standard criteria ${ }^{13}$ (Table 1). All soil parameters were grouped into four classes of suitability, viz. highly suitable, moderately suitable, marginally suitable and not suitable based on suitability criteria ${ }^{14}$.

Digital elevation model (DEM) $10 \mathrm{~m}$ data generated from Cartosat-1 satellite imagery were used for the extraction of physiographic parameters, viz. elevation, slope and aspect using ArcGIS 10.2 software. Automatic weather station (AWS) data of four stations (Amlarem ISRO0048_15F030, Jowai - ISRO0042_15F02A, Kalline - ISRO1067_15F42B and Kkeirihat-ISRO0043 15F02B) were utilized for generating spatial database of climatic parameters, viz. average annual rainfall and mean temperature using interpolation technique in ArcGIS 10.2. Kriging method was used to interpolate the climatic data because in this method low value within the optional output variance of prediction raster indicates a high degree of confidence in the predicted value. It is more rational than any other traditional methods used for interpolation. Further, kriging estimates are known to be unbiased and have minimum variance ${ }^{15}$. The rainfall and temperature data were grouped into four classes of suitability, viz. highly suitable, moderately suitable, marginally suitable and not suitable based on suitability criteria for turmeric crop $^{14}$ (Table 2).

\section{Criteria adopted for site selection}

The GIS database pertaining to soil, slope, aspect, elevation and climatic parameters was categorized into four classes according to the level of suitability, i.e. high, moderate, marginal and not suitable following standard 
Table 1. Criteria for land capability classification ${ }^{13}$

\begin{tabular}{|c|c|c|c|c|c|c|}
\hline $\begin{array}{l}\text { Land } \\
\text { capability } \\
\text { class }\end{array}$ & Soil texture & $\begin{array}{c}\text { Soil } \\
\text { erosion }\end{array}$ & $\begin{array}{l}\text { Soil depth } \\
\quad(\mathrm{cm})\end{array}$ & Permeability & $\begin{array}{l}\text { Slope } \\
(\%)\end{array}$ & $\begin{array}{c}\text { Distance from } \\
\text { active gully head }\end{array}$ \\
\hline I & Silty clay loam, clay loam, loam, silt loam & Slight & 100 & Moderate & $0-1$ & More than $60 \mathrm{~m}$ \\
\hline II & Silty clay loam, silt loam & Moderate & $50-100$ & Moderately slow & $1-5$ & Minimum $60 \mathrm{~m}$ \\
\hline III & Loamy sand, sand, silty clay & Severe & $25-50$ & Slow and rapid & $3-10$ & Between 6 and $60 \mathrm{~m}$ \\
\hline IV & Clay & Severe & $10-25$ & Very slow & $10-33$ & - \\
\hline $\mathrm{V}$ & \multicolumn{6}{|c|}{ Same characteristics as class-I, except for one or more limitations of wetness } \\
\hline VI & Clay & $\begin{array}{l}\text { Gullied la } \\
\text { sand dune }\end{array}$ & or 10 or less & Very rapid & $>33$ & Marginal land \\
\hline
\end{tabular}

Table 2. Suitability criteria for turmeric crop ${ }^{14}$

\begin{tabular}{|c|c|c|c|c|c|}
\hline \multirow[b]{2}{*}{ Site characteristics } & & \multicolumn{4}{|c|}{ Suitability criteria } \\
\hline & & High & Moderate & Marginal & Not suitable \\
\hline \multirow[t]{3}{*}{ Physiography } & Elevation (m) & $500-1000$ & $1000-1500$ & $1500-2000$ & $>2000$ \\
\hline & Slope $(\%)$ & $0-3$ & $3-8$ & $8-15$ & $>15$ \\
\hline & Aspect & $\begin{array}{l}\text { Flat, southeast, } \\
\text { south }\end{array}$ & Southwest & $\begin{array}{l}\text { Northeast, } \\
\text { east, west }\end{array}$ & $\begin{array}{l}\text { North, } \\
\text { northwest }\end{array}$ \\
\hline \multirow[t]{6}{*}{ Soil } & Drainage & Well-drained & $\begin{array}{l}\text { Moderately } \\
\text { well-drained }\end{array}$ & $\begin{array}{l}\text { Imperfectly } \\
\text { drained }\end{array}$ & $\begin{array}{l}\text { Poorly } \\
\text { drained }\end{array}$ \\
\hline & Land capability classes (LCC) & II & III & IV & VI \\
\hline & $\mathrm{pH}$ & $5.8-7.0$ & $4.8-5.7$ & $4.5-4.7$ & $<4.5$ \\
\hline & & & $7.1-7.5$ & $7.6-8.5$ & $>8.5$ \\
\hline & $\mathrm{P}_{2} \mathrm{O}_{5}(\mathrm{~kg} / \mathrm{ha})$ & $>56$ & $22.5-56$ & $<22.5$ & - \\
\hline & $\mathrm{K}_{2} \mathrm{O}(\mathrm{kg} / \mathrm{ha})$ & $>337.5$ & $136-337.5$ & $<136$ & - \\
\hline \multirow{2}{*}{ Climate } & Mean temperature $\left({ }^{\circ} \mathrm{C}\right)$ & $28-32$ & $20-27$ & $10-19$ & $<10$ \\
\hline & & & $33-37$ & $38-40$ & $>40$ \\
\hline
\end{tabular}

criteria $^{14}$. Table 2 shows the criteria for identification of suitable sites for turmeric cultivation in the Jaintia Hills district of Meghalaya. Each thematic layer had been divided into four different suitability classes, viz. highly suitable, moderately suitable, marginally suitable and unsuitable/not suitable. All input vector layers were converted to raster layers and maintained for further processing using AHP.

\section{MCDM approach}

In MCDS approach, several criteria were combined to form a single index for evaluation. Each thematic layer has a genuine importance based on the weightage that has been allocated through the GIS platform in MCDM. GIS platforms are best suited to handle a wide range of multispatial, temporal and multi-scale data using cost-effective approach and in a timely manner. AHP is a MCDM tool which decomposes complex problems into a hierarchy, and helps in solving problems and making logical decisions ${ }^{16}$. AHP judges thematic layers with the help of pairwise comparison matrix (Table 3 ). The weightages are finally aggregated.

\section{Decision rule generation using AHP}

AHP is a complex mathematical process used for solving decision-making problems. Using pairwise comparison, AHP calculates a weight for each criterion $\left(w_{i}\right)$ by taking the eigenvector analogous to the largest eigenvalue of the matrix, finally normalizing the sum of the criteria to unity $^{17}$.

$$
\sum_{i=1}^{n} w_{i}=1 .
$$

Rank was calculated for each criterion using Saaty's scaling ratio ${ }^{7}$. An equation of $n \times n$ order can be defined as

$$
A=\left[a_{i j}\right], i, j=1,2,3, \ldots, n,
$$

where $a_{i j}$ are the elements of matrix $A$ and the matrix displays the property of reciprocity, which is described as follows

$$
a_{i j}=\frac{1}{a_{j i}},
$$




\section{RESEARCH ARTICLES}

Table 3. Pairwise comparison matrix for turmeric using analytical hierarchical process

\begin{tabular}{|c|c|c|c|c|c|c|c|c|c|c|}
\hline Class & Elevation & Slope & Aspect & $\mathrm{LCC}$ & Soil pH & $\mathrm{P}_{2} \mathrm{O}_{5}$ & $\mathrm{~K}_{2} \mathrm{O}$ & Soil drainage & Rainfall & Temperature \\
\hline $\mathrm{LCC}$ & 7 & 4 & 6 & 1 & 3 & 5 & 5 & 2 & 9 & 9 \\
\hline Drainage & 7 & 4 & 7 & 0.50 & 3 & 5 & 5 & 1 & 8 & 9 \\
\hline Soil pH & 6 & 2 & 5 & 0.33 & 1 & 4 & 4 & 0.33 & 7 & 7 \\
\hline Slope & 4 & 1 & 3 & 0.25 & 0.50 & 2 & 2 & 0.25 & 5 & 5 \\
\hline $\mathrm{K}_{2} \mathrm{O}$ & 4 & 0.50 & 3 & 0.50 & 0.25 & 2 & 1 & 0.20 & 5 & 5 \\
\hline $\mathrm{P}_{2} \mathrm{O}_{5}$ & 3 & 0.50 & 2 & 0.50 & 0.25 & 1 & 0.50 & 0.20 & 4 & 4 \\
\hline Aspect & 2 & 0.25 & 1 & 0.17 & 0.50 & 0.50 & 0.33 & 0.14 & 3 & 4 \\
\hline Elevation & 1 & 0.33 & 0.50 & $1 / 7$ & 0.17 & 0.33 & 0.25 & 0.14 & 2 & 3 \\
\hline Rainfall & 0.50 & 0.20 & 0.33 & 0.14 & 0.14 & 0.25 & 0.50 & 0.13 & 1 & 2 \\
\hline Temperature & 0.33 & 0.20 & 0.25 & 0.11 & 0.14 & 0.25 & 0.20 & 0.11 & 0.50 & 1 \\
\hline Column total & 34.83 & 12.98 & 28.08 & 3.50 & 8.95 & 20.33 & 18.78 & 4.50 & 44.50 & 49.00 \\
\hline
\end{tabular}

After generation of $a_{i j}$ matrix, it is then normalized again as matrix $B$.

$$
B=\left[b_{i j}\right], i, j=1,2,3, \ldots, n,
$$

where $B$ is normalized to $A$.

$$
B=\frac{a_{i j}}{\sum_{i=1}^{n} a_{i j}=1,2,3, \ldots, n} .
$$

Finally, each weight for each layer is calculated as

$$
w_{i}=\frac{\sum_{j=1}^{n} b_{i j}}{\sum_{i=1}^{n} \sum_{j=1}^{n} b_{i j}}, i, j=(1,2,3, \ldots, n) .
$$

For matrix $B$, the relationship between the largest eigenvalue $\left(\lambda_{\max }\right)$ and the corresponding eigenvector $(W)$ is represented using eqs (7)-(9)

$$
B W=\lambda_{\max } W,
$$

To check the consistency of the pairwise matrix we calculated the consistency index (CI) and finally consistent ratio (CR). The latter provides information about the likelihood or randomness in the result of pairwise comparison matrix.

$$
\mathrm{CR}=\frac{\mathrm{CI}}{\mathrm{RI}}
$$

Consistency index can be calculated as follows

$$
\mathrm{CI}=\lambda_{\max }-\left(\frac{n}{n-1}\right) .
$$

If the calculated CR is less than 0.01 , the weightages of different thematic layers are considered to be consistent. If not, there is a need of reconsideration and reconstruction of the pairwise comparison matrix ${ }^{10,18}$.

\section{Turmeric potential index generation using AHP}

Overlaying using AHP, different thematic layers were multiplied to their respective priority vectors. Ranks had already been decided with the help of experts to judge the importance of each subclass inside a thematic layer.

In this study the following formulae have been used to overlay different thematic layers

$$
\begin{aligned}
\mathrm{TPI}= & L \times \mathrm{PV}+D \times \mathrm{PV}+\mathrm{SP} \times \mathrm{PV}+S \times \mathrm{PV} \\
& +K \times \mathrm{PV}+P \times \mathrm{PV}+A \times \mathrm{PV}+E \times \mathrm{PV}+R \times \mathrm{PV} \\
& +(T \times \mathrm{PV})=L \times 0.27+D \times 0.24+\mathrm{SP} \times 0.15 \\
& +S \times 0.092+K \times 0.077+P \times 0.058+A \times 0.041 \\
& +E \times 0.031+R \times 0.021+(T \times 0.017),
\end{aligned}
$$

where TPI, $E, S, A, L, \mathrm{SP}, P, K, D, R$ and $T$ represent turmeric potential index, elevation, slope, aspect, LCC, soil $\mathrm{pH}$, available phosphorus, available potassium, drainage, average annual rainfall and mean temperature respectively. PV is the priority vector value for each respective theme.

\section{Class size decision}

Suitability zones were classified using generated mean $(\bar{x})$ and standard deviation $(\sigma)$ from TPI, as follows

$$
\begin{aligned}
& \text { Not suitable }=\mathrm{TPI} \leq \bar{x}-\sigma . \\
& \text { Marginally suitable }=\mathrm{TPI} \geq \bar{x}-\sigma \text { and } \mathrm{TPI} \leq \bar{x} . \\
& \text { Moderately suitable }=\mathrm{TPI}>\bar{x} \text { and } \mathrm{TPI}<\bar{x}+\sigma . \\
& \text { Highly suitable }=\mathrm{TPI} \geq \bar{x}+\sigma .
\end{aligned}
$$

\section{Calculation of TPI using WOA}

In case of WOA, to make the calculation easier we have normalized the sum of weightages as 1 (one). Ranks 


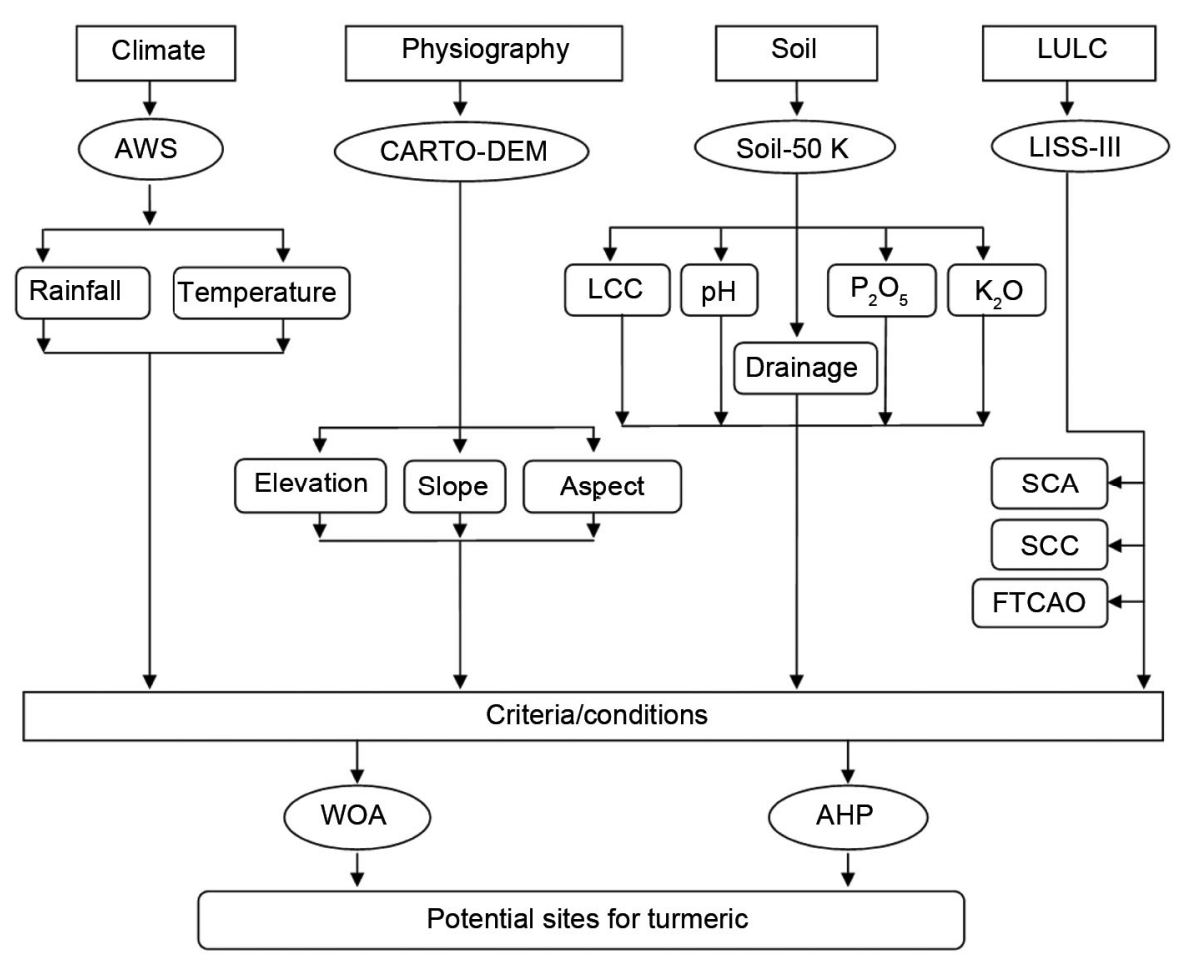

Figure 2. Overall methodology adopted for weighted overlay analysis (WOA) and analytical hierarchical process (AHP).

represent the importance of subclasses of a particular theme. The sum of the ranks of individual themes was 100 (ref. 19). The potential turmeric cultivation zones were obtained by overlaying all the thematic maps through weighted overlay methods using ArcGIS software. Figure 2 provides a stepwise description of the methodology used.

TPI was generated as the sum of the product of weightage and rank of each thematic layer, using the following formula ${ }^{20}$

$$
\text { TPI }=\frac{\left(\begin{array}{c}
\text { Ewr }+ \text { Swr }+ \text { Awr }+ \text { Lwr }+ \text { SPwr }+ \\
\text { Pwr }+ \text { Kwr }+ \text { Dwr }+ \text { Rwr }+ \text { Twr }
\end{array}\right)}{\text { Total weightage }}
$$

where wr denotes product of weightage and rank for each layer, and E, S, A, L, SP, P, K, D, R and T represent elevation, slope, aspect, $\mathrm{LCC}$, soil $\mathrm{pH}$, available phosphorus, available potassium, drainage, average annual rainfall and mean temperature respectively.

\section{Results and discussion}

It was observed that FTCAO occupied the largest area $(42.08 \%$ of TGA) followed by WL (25.47\%), FL (24.85\%), BUL (3.27\%), AL (2.98\%), WB (0.93\%), SCC $(0.34 \%)$ and SCA $(0.07 \%)$ in Jaintia Hills (Figure 3 and Table 4). FTCAO, SCC and SCA were considered for identification of suitable sites for turmeric cultivation (Figure 3 and Table 4). The producer's accuracy, user's accuracy, overall accuracy and KHAT were found to be $72.22-100.00 \%, 72.22-100 \%, 0.84$ and 0.78 respectively (Table 5).

The entire study area was divided into three classes based on elevation, i.e. highly suitable (500-1000 m), moderately suitable (1000-1500 m) and marginally suitable $(1500-2000 \mathrm{~m})$ for turmeric cultivation. It was observed that $58.8 \%$ of TGA was highly suitable, $41 \%$ moderately suitable and $0.2 \%$ marginally suitable for turmeric cultivation in Jaintia Hills based on elevation (Figure 3). Again, the study area was classified into seven slope classes, i.e. $0-1 \%, 1-3 \%, 3-8 \%, 8-15 \%, 15-33 \%$, $33-50 \%$ and $>50 \%$ (Figure 3 ). It was observed that only $6 \%$ each of TGA was highly suitable and moderately suitable, and $13 \%$ of TGA was marginally suitable for turmeric cultivation in Jaintia Hills. However, 75\% of TGA was found to be unsuitable for turmeric cultivation (Figure 3). Jaintia Hills was also classified into nine aspect classes, viz. east, flat, north, northeast, northwest, south, southeast, southwest and west (Figure 3). It was observed that $34 \%$ of TGA was highly suitable, $12 \%$ moderately suitable and $49 \%$ marginally suitable for turmeric cultivation in Jaintia Hills. Also, 5\% area was found to be unsuitable for turmeric cultivation in Jaintia Hills based on aspect (Figure 3).

Soil drainage was categorized into three classes, viz. well-drained area, moderately well-drained area and 

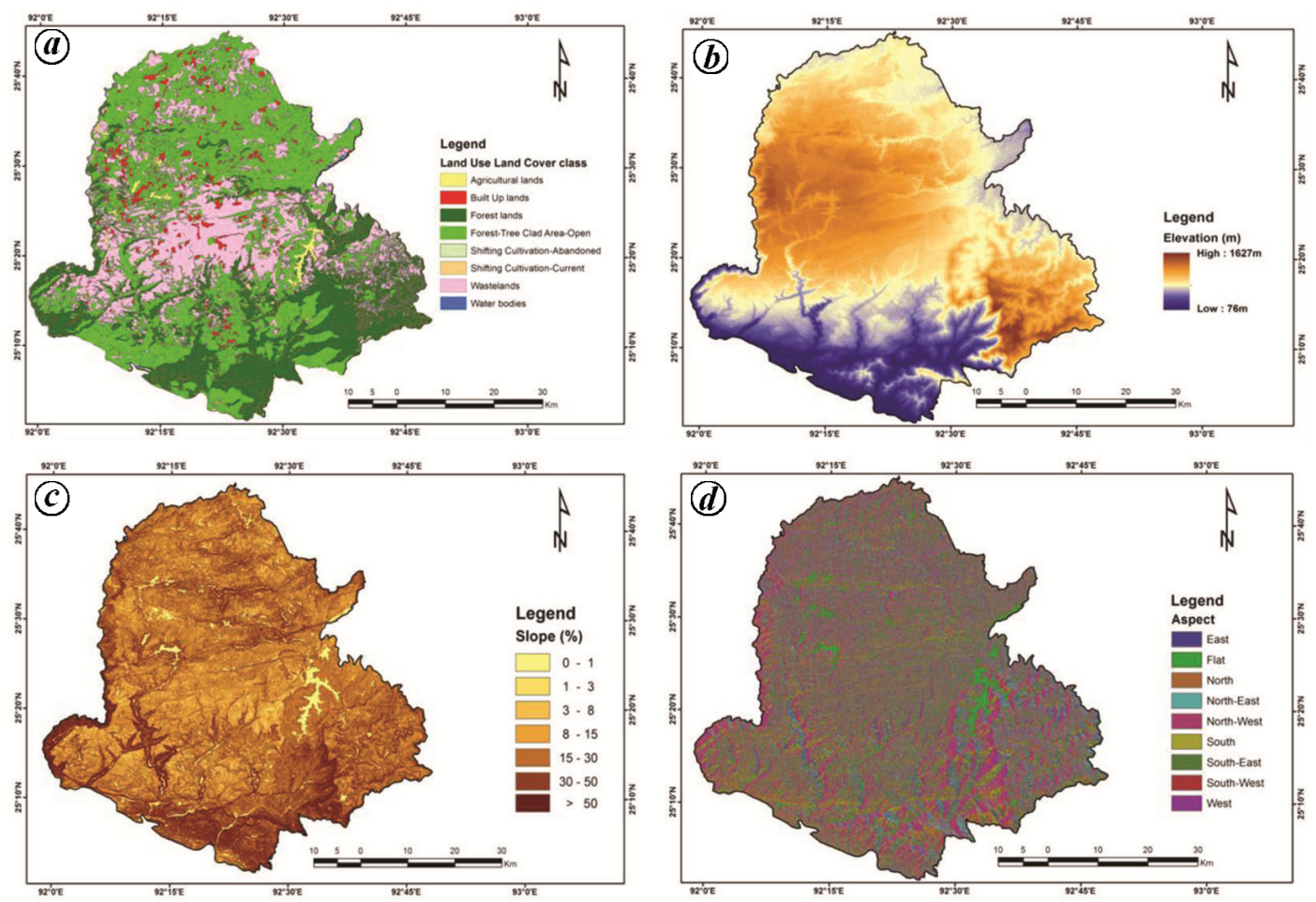

Figure 3. (a) Land-use land-cover (LULC), (b) elevation, (c) slope and (d) aspect of Jaintia Hills.

Table 4. Area under different land-use land-cover (LULC) classes in Jaintia Hills, Meghalaya, India

\begin{tabular}{lrc}
\hline LULC class & Area (ha) & $\begin{array}{c}\text { Total geographical } \\
\text { area (\%) }\end{array}$ \\
\hline Agriculture land & $11,379.52$ & 2.98 \\
Built-up land & $12,507.05$ & 3.27 \\
Forest land & $94,916.39$ & 24.85 \\
Tree-clad area open & $160,713.30$ & 42.08 \\
Shifting-abandoned & 248.35 & 0.07 \\
Shifting-current & $1,302.07$ & 0.34 \\
Wastelands & $97,279.85$ & 25.47 \\
Water bodies & $3,553.49$ & 0.93 \\
Total & $381,900.00$ & 100.00 \\
\hline
\end{tabular}

poorly drained area (Figure 4). However, habitation and water bodies were not classified. It was observed that $52 \%$ area was moderately suitable, $42 \%$ highly suitable and $2 \%$ marginally suitable for turmeric cultivation in Jaintia Hills based on soil drainage (Figure 4). Again, four LCCs were found in Jaintia Hills, namely II, III, IV and VI. However, areas under habitation and water bodies were excluded from the classification since we were only dealing with shifting cultivation areas and tree-clad areas. Only $9 \%$ area under LCC II was highly suitable for turmeric cultivation (Figure 4).

Soils of Jaintia Hills were classified into extremely acidic, very strongly acidic, strongly acidic, moderately acidic, slightly acidic and neutral based on soil $\mathrm{pH}$
(Figure 4). It was observed that $38 \%$ of TGA was highly suitable, $43 \%$ areas were moderately suitable and $12 \%$ marginally suitable for turmeric cultivation in Jaintia Hills based on soil acidity. Rest of the areas, including habitation and water bodies were considered as unsuitable for turmeric cultivation (Figure 4). Again, available $\mathrm{P}_{2} \mathrm{O}_{5}$ was found to be medium $(22.5-56 \mathrm{~kg} / \mathrm{ha})$ to high ( $56 \mathrm{~kg} / \mathrm{ha}$ ) (Figure 4$)$. It was observed that $69 \%$ of TGA was highly suitable and $27 \%$ moderately suitable for turmeric cultivation in Jaintia Hills based on available $\mathrm{P}_{2} \mathrm{O}_{5}$ (Figure 4). Similarly, available $\mathrm{K}_{2} \mathrm{O}$ was categorized into three classes, viz. low $(<136 \mathrm{~kg} / \mathrm{ha})$, medium (136$337.5 \mathrm{~kg} / \mathrm{ha}$ ) and high (>337.5 kg/ha) (Figure 4). It was observed that $54 \%$ of TGA was moderately suitable, $35 \%$ was highly suitable and 7\% was marginally suitable for turmeric cultivation in Jaintia Hills based on available $\mathrm{K}_{2} \mathrm{O}$ content (Figure 4).

Average annual rainfall of Jaintia Hills was found to vary from 1533 to $4355 \mathrm{~mm}$. High rainfall occurred in the southern and central parts of Jaintia Hills and low rainfall was recorded in the northwestern part. The entire region was found to be highly suitable for turmeric cultivation based on average annual rainfall (Figure 5). The mean temperature in Jaintia Hills varied from $17^{\circ} \mathrm{C}$ to $23^{\circ} \mathrm{C}$. The southeastern part was found to be warmer compared to the other areas. The lowest temperature was observed around the western parts of Jaintia Hills (Figure 5). It was observed that $54 \%$ of TGA was highly suitable and $46 \%$ was moderately suitable for turmeric 
Table 5. Accuracy assessment of LULC of Jaintia Hills ${ }^{12}$

\begin{tabular}{|c|c|c|c|c|c|c|c|}
\hline \multirow[b]{2}{*}{ LULC } & \multicolumn{5}{|c|}{ Referenced data } & \multirow[b]{2}{*}{ Row total } & \multirow[b]{2}{*}{ User's accuracy } \\
\hline & $\mathrm{AL}$ & BUL & FL/FTCAO & $\mathrm{SCC} / \mathrm{SCA}$ & WL & & \\
\hline \multicolumn{8}{|l|}{ Classified data } \\
\hline $\mathrm{AL}$ & 13 & & & & 1 & 14 & 92.86 \\
\hline BUL & 2 & 13 & 2 & & 1 & 18 & 72.22 \\
\hline FL/FTCAO & & & 12 & & & 12 & 100.00 \\
\hline $\mathrm{SCC} / \mathrm{SCA}$ & & & & 1 & & 1 & 100.00 \\
\hline WL & 3 & 2 & 1 & & 24 & 30 & 80.00 \\
\hline Column total & 18 & 15 & 15 & 1 & 26 & 75 & \\
\hline Producer accuracy & 72.22 & 86.67 & 80.00 & 100.00 & 92.31 & & \\
\hline Overall accuracy & & & & 0.84 & & & \\
\hline KHAT & & & & 0.78 & & & \\
\hline
\end{tabular}

LULC, Land-use land-cover; AL, Agricultural land; BUL, Built-up land; FL, Forest land; FTCAO, Forest-tree clad area-open; SCC, Shifting cultivation-current; SCA, Shifting cultivation-abandoned; WL, Wastelands.
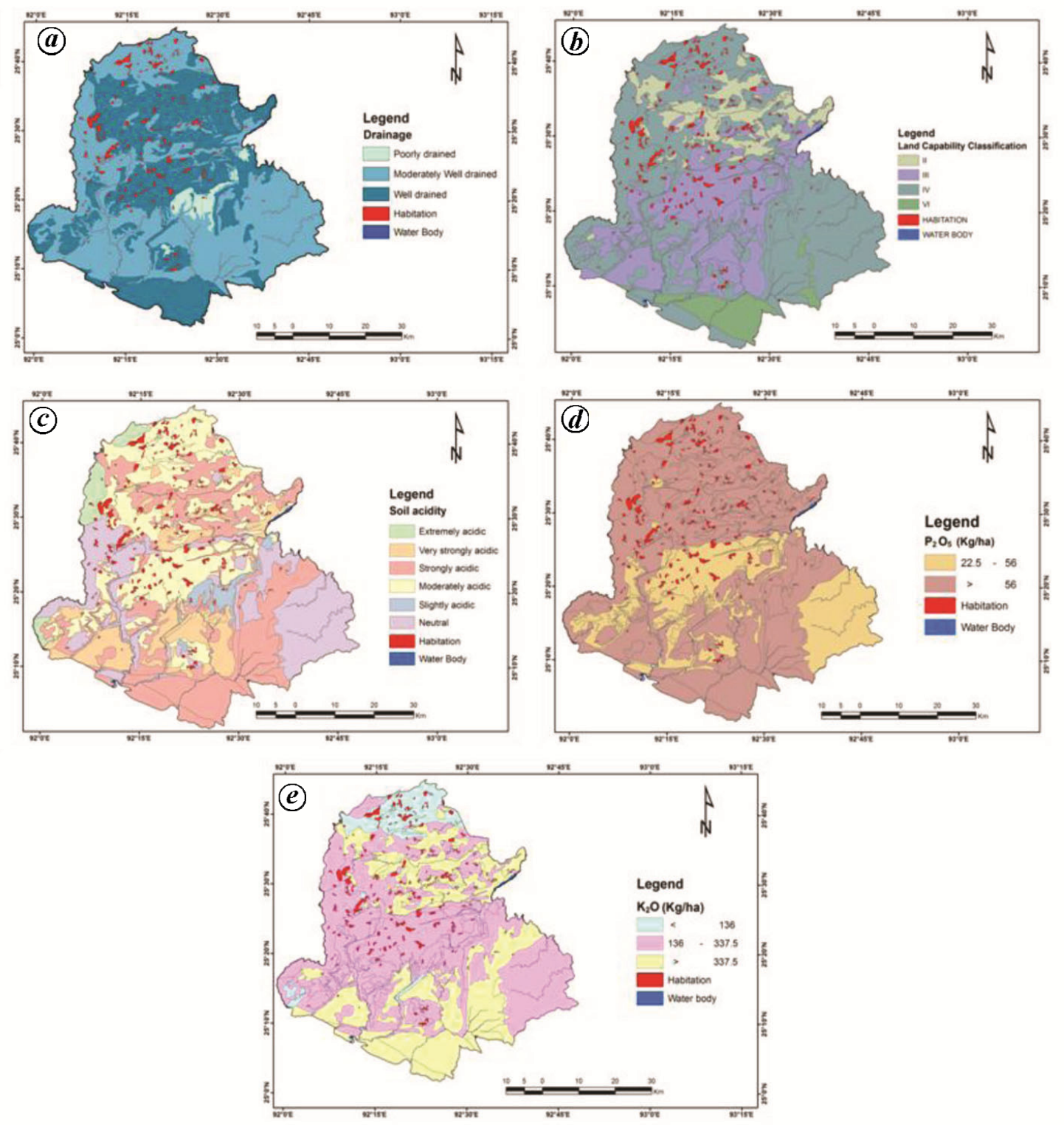

Figure 4. (a) Soil drainage, (b) land capability classes (LCC), (c) soil acidity, (d) available $\mathrm{P}_{2} \mathrm{O}_{5}$ and (e) available $\mathrm{K}_{2} \mathrm{O}$ of Jaintia Hills. 

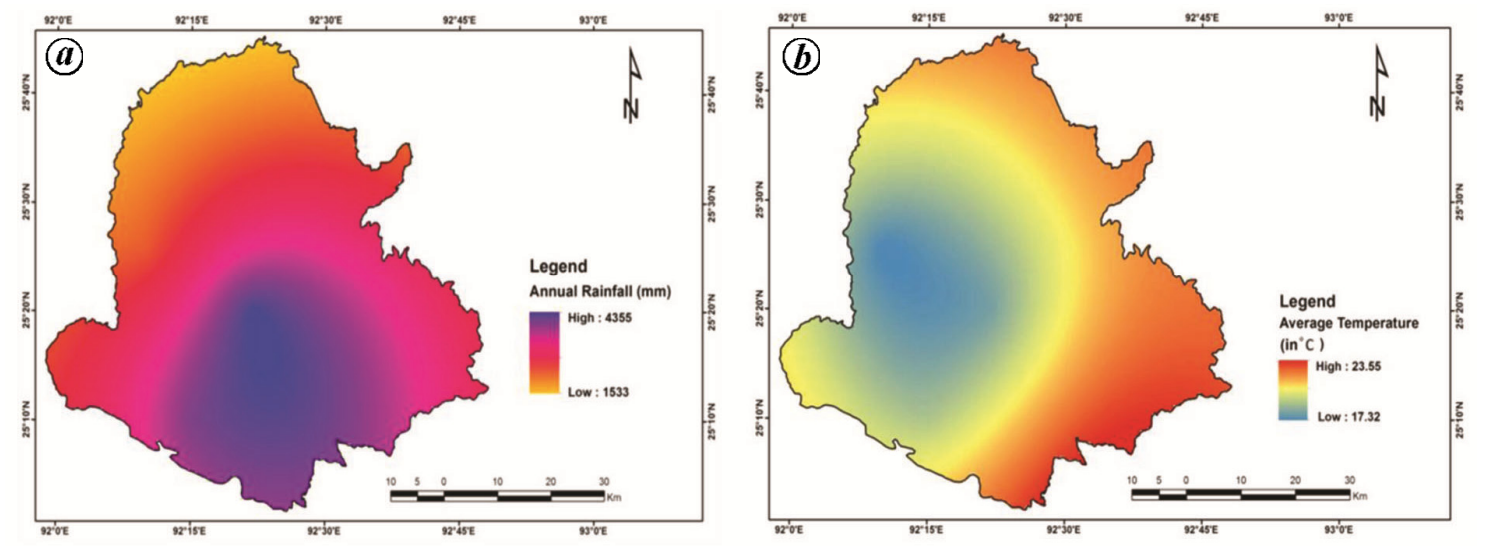

Figure 5. Spatial distribution of (a) mean annual rainfall and (b) mean temperature in Jaintia Hills.
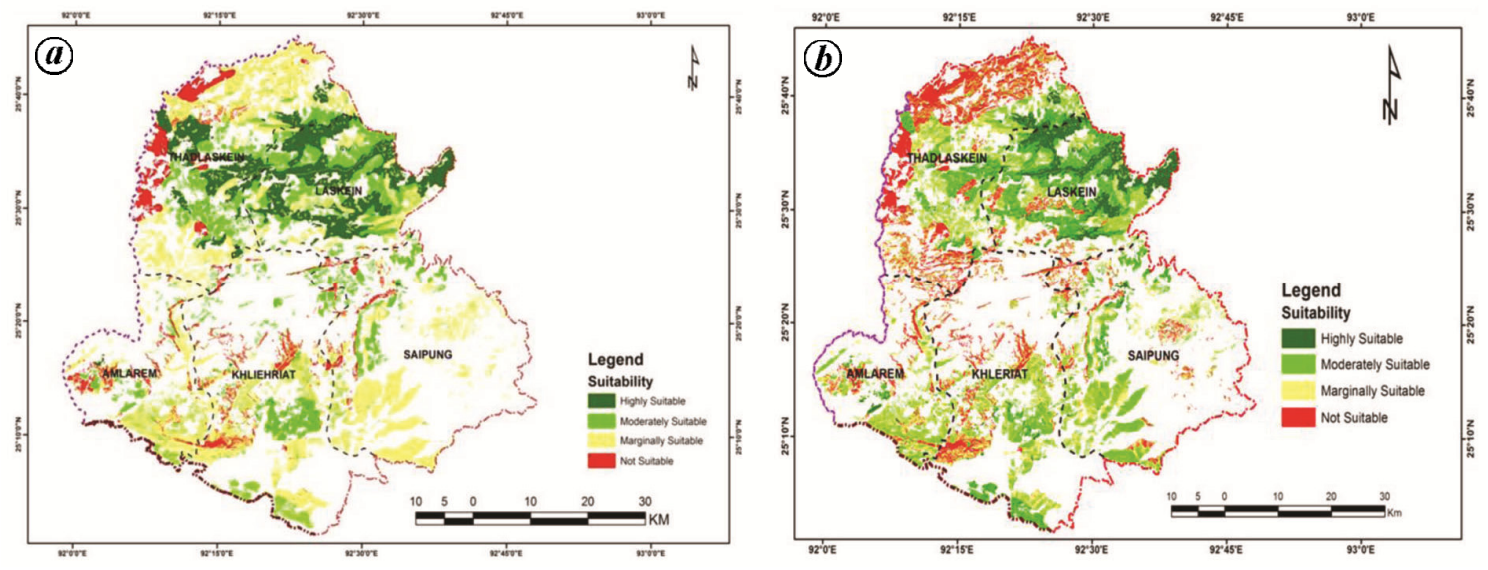

Figure 6. Suitable sites of turmeric cultivation generated using (a) AHP and (b) WOA in Jaintia Hills.

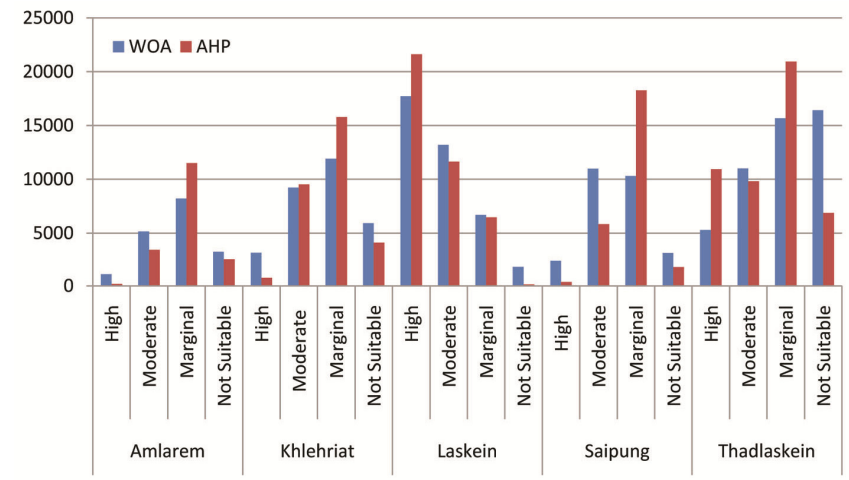

Figure 7. Suitable areas for turmeric cultivation in Community and Rural Development blocks of Janitia Hills.

cultivation. The whole area was found to be suitable for turmeric cultivation based on temperature in Jaintia Hills (Figure 5).

\section{Site suitability analysis for turmeric cultivation using AHP}

AHP yielded a different result compared to WOA for site suitability analysis. There was a sharp decrease (by 10\%) in the unsuitable area. Again, marginally suitable areas occupied a sum of $72,967.48$ ha ( $45 \%$ of TGA). Similarly, moderately suitable and highly suitable areas occupied $25 \%$ and $21 \%$ of TGA respectively. Laskein Community and Rural Development (C\&RD) block represented highest area under highly suitable class $(21,624.35$ ha, $64 \%$ of TGA), while lowest area under highly suitable class was found in Amlarem C\&RD block (192.57 ha, $<1 \%$ of TGA). Thadlaskein and Khlehriat represented highest unsuitable areas for turmeric cultivation (45\% and $26 \%$ of TGA respectively). Figures 6 and 7 show suitable areas for turmeric cultivation in Jaintia Hills generated using AHP and WOA.

\section{Site suitability analysis for turmeric cultivation using $W O A$}

Potential sites for turmeric cultivation were categorized into four classes, viz. highly suitable, moderately suitable, marginally suitable and not suitable. The study revealed that $29,534.47$ ha was highly suitable $(18 \%)$, $49,590.75$ ha was moderately suitable $(31 \%)$ and $52,785.47$ ha was marginally suitable $(32 \%)$ for turmeric 


\section{RESEARCH ARTICLES}

cultivation in Jaintia Hills. However, 30,353.02 ha was found to be unsuitable (19\%) for turmeric cultivation. Jaintia Hills consists of five C\&RD blocks, viz. Amlarem, Khlehriat, Laskein, Saipung and Thadlaskein. The largest areas under highly suitable category for turmeric cultivation were found in Laskein $(10.92 \%)$ followed by Thadlaskein (3.26\%), Khleriet (1.90\%), Saipung (1.44\%) and Amlarem (0.67\%). Similarly, the proportion of moderately suitable area found in Laskein was $(8.14 \%)$ followed by Thadlaskein (6.78\%), Saipung (6.77\%), Khlehriet (5.70\%) and Amlarem (3.17\%). On the other hand, 9.66\% area in Thadlaskein, $7.34 \%$ in Khleriet, $6.34 \%$ in Saipung, 5.06\% in Amlarem and 4.12\% area in Laskein were found to be marginally suitable for turmeric cultivation (Figures 6 and 7).

\section{Conclusion}

The present study reveals that a large extent of areas is underutilized in Jaintia Hills which can be brought under cultivation. Even when we consider the highly suitable areas, which is nearly 40,000 ha, there is huge potential for the region to increase area under turmeric crop. Quick satellite data acquisition, management, processing and understanding seasonal variability are some of the added advantages. This study has demonstrated the strength of remote sensing and geographic information system in the identification of potential sites for turmeric cultivation in Jaintia Hills of Meghalaya; however, the problem lies in determining in validation and extent of veracity for both the methods.

In general, AHP is considered to be superior to WOA since it gives a valid confirmation of weightage using CR. Although WOA and AHP are based on overlaying different thematic layers according to weightage and rank among the numerous parameters within the layer, weighted analysis solely depends on experts' knowledge for the determination of weight and rank, which can vary according to the one's judgement.

1. Moorthi, C. and Kathiresan, K., Curcumin-piperine/curcuminquercetin/curcumin-silibinin dual drug-loaded nanoparticulate combination therapy: a novel approach to target and treat multidrug-resistant cancers. J. Med. Hypotheses Ideas, 2013, 7(1), 15-20.

2. Mandal, D. K., Khule, S., Mandal, C., Lal, S., Hajare, N. and Prasad, J., Soil suitability evaluation for turmeric in Wardha district of Maharashtra. Agropedology, 2008, 18(2), 83-92.

3. Rahman, S. A., Baldauf, C., Mollee, E. M., Abdullah-Al-Pavel, M., Abdullah-Al-Mamun, M., Toy, M. M. and Sunderland, T., Cultivated plants in the diversified homegardens of local communities in Ganges Valley, Bangladesh. Sci. J. Agric. Res. Manage, 2013

4. Benzie, I. F. and Wachtel, G. S., Herbal Medicine: Biomolecular and Clinical Aspects, 2nd edn, CRC Press, Florida, USA, 2011.
5. Asati, B. S. and Yadav, D. S., Diversity of horticultural crops in north eastern region. ENVIS Bull.: Himalayan Ecol., 2004, 12(1), 1.

6. Deshmukh, N. A. Jha, A. K., Verma, V. K., Rymbai, H., Deka, B. C. and Ngachan, S. V., Megha Turmeric-1: popularization through farmers' participatory mode in Meghalaya: a success story, ICAR Research Complex for NEH Region, Meghalaya, 2017.

7. Saaty, T. L. and Vargas, G. L., Models Methods, Concepts and Applications of the Analytical Heirarchy Process, Kluwer, Boston, USA, 2001.

8. Semlani, I., Ouadif, L. and Bahi, L., Landslide susceptibility mapping using the analytical heirarchy process and GIS. Curr. Sci., 2019, 116(5), 773-779.

9. Saaty, T. L., The Analytical Heirarchy Process, McGraw Hill, New York, USA, 1980.

10. Nandy, S., Kushwaha, S. P. S. and Gaur, P., Identification of swamp deer (Cervus duvauceli Cuvier) potential habitat in Jhilmil Jheel Conservation Reserve, Uttarakhand, India using multicriteria analysis. Environ. Manage., 2012, 49(4), 902-914.

11. Bhalerao, A. K., Kumar, B., Singha, A. K., Jat, P. C., Bordoloi, R. and Deka, B. C., Cachar District Inventory of agriculture, ICARAgricultural Technology Application Research Institute, Umiam, Meghalaya, 2015.

12. Congalton, R. G., Accuracy assessment and validation of remotely sensed and other spatial information. Int. J. Wildland Fire, 2001, 10(4), 321-328.

13. Mohan, S. C., Samra, J. S. Srivastava, A. K. and Sharda, V. N., Training Manual for Soil Conversation and Watershed Management, Soil, Agronomy and Socio-Economic Aspects, Central Soil and Water Conversation Research and Training Institute, Dehradun, 2007, vol. 1, p. 93.

14. Naidu, L. G. K., Ramamurthy, V., Challa, O., Hegde, R. and Krishnan, P., Soil-Site Suitability for Major Crops, NBSS Publication No. 129, 2006.

15. Oliver, M. A. and Webster, R., Kriging: a method of interpolation for geographical information systems. Int. J. Geogr. Inform. Syst., 1990, 4(3), 313-332.

16. Triantaphyllou, E., Multi-criteria decision making methods. In Multi-criteria Decision Making Methods: A Comparative Study, Springer, Boston, MA, USA, 2000, pp. 5-21.

17. Saaty, T. L., Decision making with the analytic hierarchy process. Sci. Iran., 2002, 9(3), 215-229.

18. Feizizadeh, B. and Blaschke, T., Land suitability analysis for Tabriz County, Iran: a multi- criteria evaluation approach using GIS. J. Environ. Plan. Manage., 2013, 56(1), 1-23.

19. Magesh, N. S., Chandrasekar, N. and Soundranayagam, J. P., Delineation of groundwater potential zones in Theni district, Tamil Nadu, using remote sensing, GIS and MIF techniques. Geosci. Front., 2012, 3(2), 189-196.

20. Arkoprovo, B., Adarsa, J. and Prakash, S. S., Delineation of groundwater potential zones using satellite remote sensing and geographic information system techniques: a case study from Ganjam district, Orissa, India. Res. J. Recent Sci., 2012, 1(9), 5966.

ACKNOWLEDGEMENTS. This work was undertaken as part of a National Programme entitled 'Coordinated Horticulture Assessment and Management using Geoinformatics' (CHAMAN) with financial assistance from Mahanalobis National Crop Forecast Centre, Department of Agriculture, Cooperation and Farmers' Welfare, Ministry of Agriculture and Farmers' Welfare, Government of India.

Received 20 March 2019; revised accepted 22 January 2020

doi: $10.18520 / \mathrm{cs} / \mathrm{v} 118 / \mathrm{i} 8 / 1246-1254$ 